\title{
Can xylene and chia (Salvia hispanica L.) seed extract directly affect basic bovine ovarian cell functions?
}

\author{
A. Tarko ${ }^{1,4}$, A. Stochmalova', S. Hrabovszka', A. Vachanova', \\ A.H. Harrath ${ }^{2}$, R. Grossman ${ }^{3}$ and A. Sirotkin ${ }^{1}$ \\ ${ }^{1}$ Constantine the Philosopher University in Nitra, 94974 Nitra, Slovakia \\ ${ }^{2}$ King Saud University, Riyadh 12372, Saudi Arabia \\ ${ }^{3}$ Friedrich Loeffner Institute, Mariensee, 31535 Neustadt am Rübenberge, Germany
}

KEY WORDS: xylene, chia, proliferation, apoptosis, hormones, ovarian granulosa cells

\begin{abstract}
It was supposed, that xylene as environmental contaminant and chia (Salvia hispanica L.) as a medicinal plant may affect ovarian cell functions, and that chia seed extract could modify the potentially adverse effect of xylene. So, the aim of our investigation was to study the effect of xylene, extract of chia seed and their combination on bovine ovarian cell functions (proliferation, apoptosis and secretory activity) in vitro. Proliferation, apoptosis and the release of hormones (insulin-like growth factor 1 (IGF-1), progesterone and testosterone) were analysed with the use of either immunocytochemistry or EIA/RIA. It was observed, that xylene when given alone stimulated proliferation and did not influence the apoptosis. Furthermore, xylene inhibited release of progesterone and testosterone but did not change the release of IGF-1. Chia seed extract inhibited proliferation, apoptosis and the release of IGF-1, progesterone and testosterone. Moreover, chia seed extract suppressed the stimulatory effect of xylene on proliferation, and added together stimulated apoptosis. The simultaneous addition of chia seed extract and xylene stimulated IGF-1 release and inhibited the release of progesterone, but not testosterone. The obtained results prove a direct effect of both xylene and chia seed extract on bovine ovarian cell proliferation, apoptosis and secretory activity. Moreover, it is the first study in which chia seed extract was able to suppress xylene effect on ovarian cell proliferation. However, it prevented only from one xylene effect among five analysed suggesting that chia seed extract could not be potentially useful for natural prevention of all negative effects of xylene on reproduction.
\end{abstract}

place (Taskinen et al., 1994). In rats xylene decreased plasma progesterone level, but not the release of this hormone by ovaries (Ungváry et al., 1981). On the other hand, the negative influence of xylene on reproduction was observed in in vivo experiments. The mechanisms of xylene action on reproductive systems (gonadal cell proliferation, apoptosis and hormones release) in vitro have not been studied yet.

It is known, that some effects of stress on ovarian functions could be prevented or neutralized by some plants containing antioxidants and other adap- able to increase the incidence of spontaneous abortions among workers exposed to xylene at the work tions in mammalian growth, development, immune , metabolism, respiratory and other functio few reports demonstrating its effect on reproduction (Sirotkin et al., 2012). It was stated that xylene was

Received: 25 November 2016
Revised: $\quad 2$ February 2017

Accepted: $\quad 13$ June 2017

\section{Introduction}


togenes (Huang and Chen, 2008; Liang and Yin, 2010), phytohormones and growth factors (Sirotkin, 2010, 2011). Among such plants is chia (Salvia hispanica L.), which seeds are currently popular functional food. Chia seeds consumption can affect a number of physiological processes including reproduction. In the literature, the abilities of chia seed extract to suppress ovarian cell functions by inhibiting porcine and rabbit ovarian cell proliferation (accumulation of proliferation marker - proliferating cell nuclear antigen (PCNA)), to promote apoptosis (accumulation of apoptosis marker - Bcl-2-associated X protein (Bax)) and to cause alteration in the production of progesterone, testosterone and leptin release have been reported (Sirotkin et al., 2015). It is not excluded, that chia seed extract may not only affect basic ovarian cell functions, but it may also modify and prevent potentially adverse effect of xylene on reproduction and fertility.

Chia seeds contain phytoestrogens and other molecules which can prevent the stress-induced pathological changes in the ovary (Sirotkin and Harrath, 2014). The analysis of the available literature shows that the action of either xylene or chia seed extract on basic ovarian functions has not been properly studied yet, whilst the ability of chia seed extract to modify the action of environmental contaminant on ovarian cells has not been previously examined. Therefore, the aim of the present in vitro experiment was to examine the effect of xylene, extract of chia seed and their combination on proliferation, apoptosis and secretory activity of bovine ovarian granulosa cells.

\section{Material and methods}

\section{Preparation, processing and culture of ovarian granulosa cells}

Ovaries of Holstein cows aged 3-5 years at a follicular stage of the oestrous cycle were obtained at slaughterhouses of Research Institute of Animal Production in Nitra (Slovakia) and in Stara Myjava (Slovakia).

The ovaries were individually stored in a thermos with a physiological solution at room temperature and processed within $6 \mathrm{~h}$ from the slaughter. Ovarian granulosa cells were isolated from follicles by the method of aspiration with syringe. After aspiration and cells isolation, the granulosa cells were washed in sterile DMEM/F12 1:1 medium (BioWhittaker ${ }^{\mathrm{TM}}$; Lonza, Verviers, Belgium), resuspended in the same medium supplemented with $10 \%$ foetal calf serum (South America Origin; Biowest, Nuaillé, France) and $1 \%$ antibiotic-antimycotic (with 10000 units penicillin, $10 \mathrm{mg}$ streptomycin and $25 \mu \mathrm{g}$ ampho- tericin B per ml, sterile-filtered, BioReagent, suitable for cell culture) solution (Sigma-Aldrich, St. Louis, MO, USA, A5955-100 ml). Cells were counted using Buerker's chamber and their concentration was adjusted to the required volume $\left(10^{6}\right.$ cells $\cdot \mathrm{ml}^{-1}$ medium). The cell suspension was diluted with culture medium, and cells were cultured at $37.5^{\circ} \mathrm{C}$ and in $5 \% \mathrm{CO}_{2}$ in 24-well culture plates $(1 \mathrm{ml}$ of suspension per well, Nunc ${ }^{\mathrm{TM}}$, Roskilde, Denmark) for RIA analysis or in 16-well chamber slides $(200 \mu$ per well, Nunc Inc., International, Naperville, IL, USA) for immunocytochemistry. After 4 days of culture when the cells formed a continuous monolayer (75\%), the medium was replaced with fresh medium with $10 \%$ foetal calf serum, $1 \%$ antibiotic-antimycotic and chia seed extract or/and xylene were added. As a result such groups were obtained: 1 . control group without chia seed extract (milled seeds extracted for 1 day in DMSO - dimethyl sulfoxide, 99.9\%) (country of origin Bolivia, packed Helpful, Dubnica nad Váhom, Slovakia), 2. three groups with chia seed extract addition $\left(1,10\right.$ and $\left.100 \mathrm{ng} \cdot \mathrm{ml}^{-1}\right)$, 3. negative control group with the addition of $99 \%$ mixture of ortho-, metha- or para-xylene $\left(20 \mathrm{ng} \cdot \mathrm{ml}^{-1}\right)$ (Carolina Biological Supply Company, Burlinghton, NC, USA) but without chia seed extract, 4 . three groups with the simultaneous addition of $99 \%$ mixture of ortho-, metha- or para-xylene $\left(20 \mathrm{ng} \cdot \mathrm{ml}^{-1}\right)$ and chia seed extract $\left(1,10\right.$ and $\left.100 \mathrm{ng} \cdot \mathrm{ml}^{-1}\right)$. After 48-hour incubation, the medium from culture plates was removed via syringe and stored at $-70{ }^{\circ} \mathrm{C}$ until further analysis with EIA/RIA. A monolayer of cells on chamberslides was fixed with $4 \%$ paraformaldehyde in phosphate buffered saline (PBS) for $10 \mathrm{~min}$ and stored at $+4{ }^{\circ} \mathrm{C}$ until immunocytochemistry analysis.

\section{Immunocytochemical analysis}

The presence of markers of proliferation (PCNA) and apoptosis (Bax) was detected by immunocytochemistry (Osborn and Isenberg, 1994).

After washing and fixation, the cells were incubated in blocking solution (1\% goat serum (Santa Cruz Biotechnology Inc., Dallas, TX, USA) in PBS) at room temperature for $1 \mathrm{~h}$ to block non-specific binding of the antiserum. The cells were incubated at the presence of monoclonal antibodies against either PCNA (dilution 1:500 in PBS; cat. no. sc-25280) or Bax (dilution 1:500 in PBS; cat. no. sc-23959, Santa Cruz Biotechnology Inc., Dallas, TX, USA). After $1 \mathrm{~h}$ of incubation at room temperature, cells were incubated with a secondary swine anti-mouse IgG (dilution 1:1000; cat. no. sc-2031, Santa Cruz Biotechnology Inc., Dallas, TX, USA) labelled with horseradish peroxidase (HRP; Servac, Prague, Czech Republic) 
for $1 \mathrm{~h}$. Positive signals were visualized by staining with 3,3'-diaminobenzidine (DAB) (K3468) substrate (Roche Diagnostics GmbH, Mannheim, Germany) for $1 \mathrm{~h}$. After DAB staining, the cells on the chamber slides were washed in PBS, and then covered with a drop of glycergel - fixation medium (DAKO, Glostrup, Denmark), and then cover slip was attached to a microslide. The presence and localization of PCNA and Bax positive cells was proved on the basis of HRP-DAB (brown staining). Cells processed without the primary antibody were used as negative control. A ratio of HRP-DAB-stained cells to the total cell number was calculated.

\section{Immunoassay}

Concentrations of IGF-1, progesterone and testosterone were determined in $25-100 \mu \mathrm{l}$ samples of incubation medium by enzyme immunoassay (EIA)/radio immunoassay (RIA). The used methods were previously validated for use in culture medium by using antisera against steroids produced in the Institute of Animal Science, Neustadt (Germany). Progesterone concentrations were measured by using EIA as described previously by Prakash et al. (1987). Rabbit antiserum against progesterone was obtained from Research Institute for Animal Production, Schoonoord (the Netherlands). It cross-reacted $<0.1 \%$ with $17 \beta$-oestradiol, dihydrotestosterone, testosterone and $17 \beta$-hydroxyprogesterone. Sensitivity was $12.5 \mathrm{pg} \cdot \mathrm{ml}^{-1}$. Inter- and intra-assay coefficients of variation did not exceed $3.3 \%$ and $3.0 \%$, respectively. Testosterone was assayed using EIA according to Münster (1989). Sensitivity was $10 \mathrm{pg} \cdot \mathrm{ml}^{-1}$. The antiserum cross-reacted $<96 \%$ with dihydrotestosterone, $<3 \%$ with androstenedione, $<0.01 \%$ with progesterone and oestradiol, $<0.02 \%$ with cortisol and $<0.001 \%$ with corticosterone. Inter- and intra-assay coefficients of variation were $12.3 \%$ and $6.8 \%$, respectively. Concentration of IGF-1 was determined after extraction with acidethanol solution $(87.5 \%$ of ethanol $+12.5 \% 2 \mathrm{~N} \mathrm{HCl}$, $\mathrm{v} / \mathrm{v})$ using RIA method as described previously by Makarevich and Sirotkin (1999). Sensitivity was $3 \mathrm{pg} \cdot \mathrm{ml}^{-1}$. Inter- and intra-assay coefficients of variation did not exceed $3.4 \%$ and $8.2 \%$, respectively.

\section{Statistical analysis}

The number of independent repetitions for immunocytochemistry experiments was three and the number of EIA/RIA repetitions was four. In these independent experiments, each experimental group was represented by four culture wells for EIA/RIA or one chamber slide well for immunocytochemistry. The proportions of cells containing specific immuno- reactivity were calculated from inspection of at least 1000 cells per chamber. Assays of hormone levels in the incubation media were performed in duplicate. The samples intended for EIA/RIA or immunocytochemistry were processed separately. The rates of substance secretion were calculated per ng $/ 10^{6}$ cells/day.

Differences between examined groups were evaluated using two-way analysis of variance (ANOVA) followed by Dunnett's post-hoc test with the use of statistical software Sigma Plot 11.0 (Systat Software, Erkrath, Germany). In the results section only the comparison between selected groups has been presented: 1. difference between cells cultured without and with chia seed extract addition at 3 different levels without xylene, 2. difference between cells cultured with or without xylene for each chia seed extract dose separately, 3. difference between cell cultured without and with chia seed extract addition at 3 different levels with simultaneous xylene addition. Values are presented as mean \pm standard error of mean (SEM). Differences were considered significant at $P<0.05$.

\section{Results}

\section{Proliferation}

Xylene $\left(20 \mathrm{ng} \cdot \mathrm{ml}^{-1}\right)$ when given alone stimulated proliferation of bovine ovarian cell, whilst chia seed extract at a dose of $100 \mathrm{ng} \cdot \mathrm{ml}^{-1}$ inhibited it.

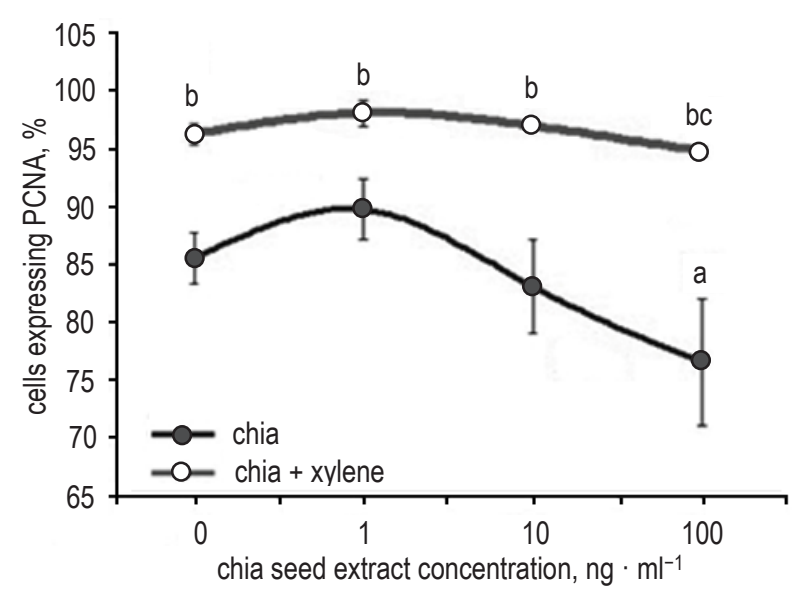

Figure 1. Effect of xylene, chia seed extract and their combination on proliferation (accumulation of proliferating cell nuclear antigen (PCNA)) in cultured bovine ovarian granulosa cells. Results were expressed as the mean \pm SEM of at least 3 independent experiments with 1 well per each treatment in each experiment; a - effect of chia (significant difference $(P<0.05)$ between cells cultured without and with chia seed extract addition at 3 different levels without xylene), $b$ - effect of xylene (significant difference $(P<0.05)$ between cells cultured with or without xylene for each chia dose separately), $\mathrm{C}$ - effect of chia seed extract at simultaneous xylene presence (significant difference $(P<0.05)$ between cell cultured with and without chia seed extract addition at 3 different levels with simultaneous $x y-$ lene addition); effect of xylene alone $\left(20 \mathrm{ng} \cdot \mathrm{ml}^{-1}\right)$ is displayed for chia seed extract dose at $0 \mathrm{ng} \cdot \mathrm{ml}^{-1}$ 
Moreover, when given together with xylene, chia seed extract $\left(100 \mathrm{ng} \cdot \mathrm{ml}^{-1}\right)$ significantly $(P<0.05)$ suppressed the stimulatory effect of xylene on proliferation (Figure 1).

\section{Apoptosis}

Xylene $\left(20 \mathrm{ng} \cdot \mathrm{ml}^{-1}\right)$ when given alone did not influence apoptosis whilst chia seed extract (at a dose 10 and $100 \mathrm{ng} \cdot \mathrm{ml}^{-1}$, but not at $1 \mathrm{ng} \cdot \mathrm{ml}^{-1}$ ) inhibited it. However, xylene and chia seed extract (at a dose 1 and $10 \mathrm{ng} \cdot \mathrm{ml}^{-1}$, but not at $100 \mathrm{ng} \cdot \mathrm{ml}^{-1}$ ) given together stimulated apoptosis (Figure 2).

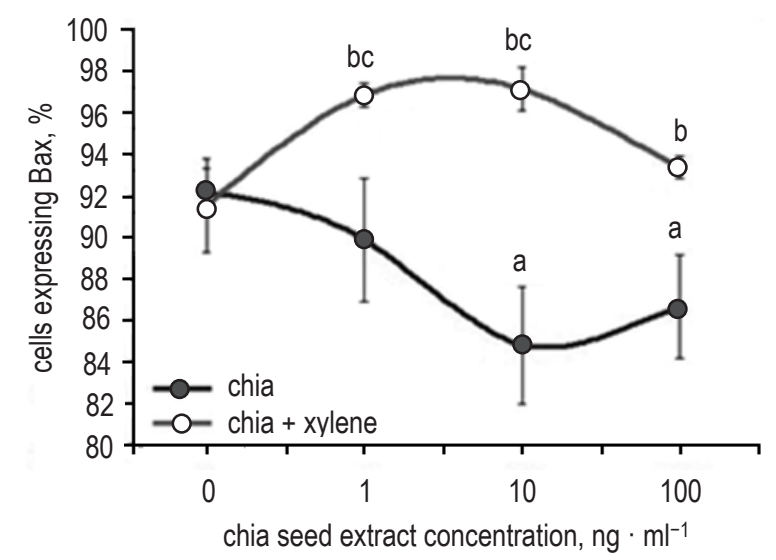

Figure 2. Effect of xylene, chia seed extract and their combination on apoptosis (accumulation of Bax) in cultured bovine ovarian granulosa cells. Results were expressed as the mean \pm SEM of at least 3 independent experiments with 1 well per each treatment in each experiment; abc - see Figure 1

\section{Hormone release}

IGF-1. Xylene $\left(20 \mathrm{ng} \cdot \mathrm{ml}^{-1}\right)$ did not affect the release of IGF-1 whilst chia seed extract ( 1 and $10 \mathrm{ng} \cdot \mathrm{ml}^{-1}$ ) inhibited it. However, chia seed extract $\left(100 \mathrm{ng} \cdot \mathrm{ml}^{-1}\right)$ and xylene given together stimulated IGF-1 release from bovine ovarian cells (Figure 3).

Progesterone. Both xylene $\left(20 \mathrm{ng} \cdot \mathrm{ml}^{-1}\right)$ and chia seed extract $\left(10\right.$ and $\left.100 \mathrm{ng} \cdot \mathrm{ml}^{-1}\right)$ when used separately inhibited release of progesterone from bovine ovarian cells. Moreover, when chia seed extract was added at a dose of $100 \mathrm{ng} \cdot \mathrm{ml}^{-1}$ together with xylene these two compounds caused more pronounced inhibitory effect (Figure 4).

Testosterone. Both xylene $\left(20 \mathrm{ng} \cdot \mathrm{ml}^{-1}\right)$ and chia seed extract (at all examined doses) when given separately inhibited testosterone release from bovine ovarian cells. Moreover the same inhibitory effect was observed when chia seed extract (at all used doses) was added simultaneously with xylene (Figure 5).

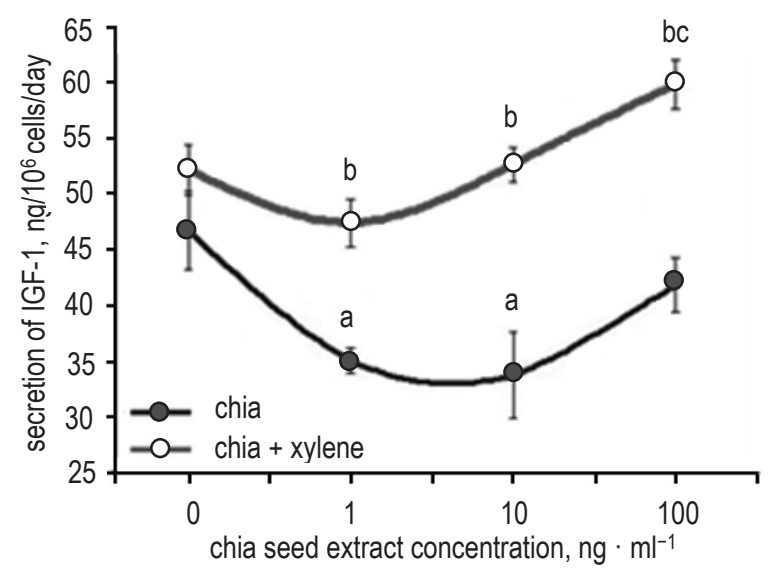

Figure 3. Effect of xylene, chia seed extract and their combination on release of IGF-1 by cultured bovine ovarian granulosa cells. Results were expressed as the mean \pm SEM of at least 3 independent experiments with 4 replicate wells per each treatment in each experiment; abc - see Figure 1

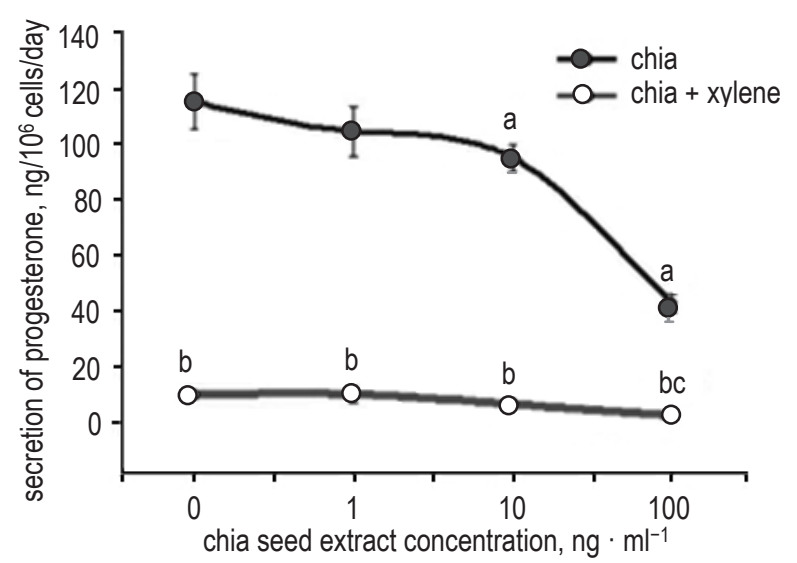

Figure 4. Effect of xylene, chia seed extract and their combination on release of progesterone by cultured bovine ovarian granulosa cells. Results were expressed as the mean \pm SEM of at least 3 independent experiments with 4 replicate wells per each treatment in each experiment; abc - see Figure 1

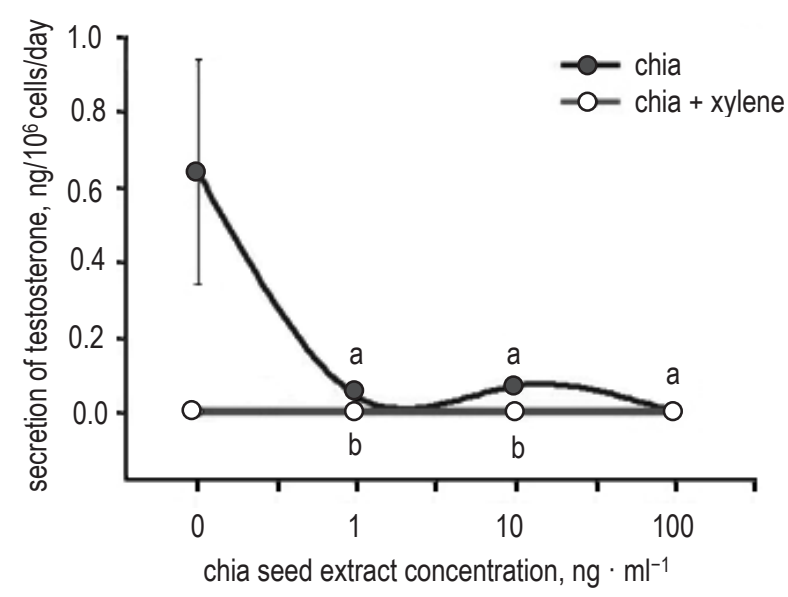

Figure 5. Effect of xylene, chia seed extract and their combination on release of testosterone by cultured bovine ovarian granulosa cells. Results were expressed as the mean \pm SEM of at least 3 independent experiments with 4 replicate wells per each treatment in each experiment; abc - see Figure 1 


\section{Discussion}

The obtained results showed, that xylene addition stimulated proliferation, but not apoptosis of bovine ovarian granulosa cells. Moreover, the inhibitory effect of xylene on the release of progesterone and testosterone was observed. These observations are in line with previous data reported by Ungváry et al. (1981) concerning the inhibitory action of xylene on blood progesterone level in rats. Our observations are the first to present the ability of xylene to promote ovarian cell proliferation but not apoptosis. Since PCNA is a marker of S-phase of mitosis (Connolly and Bogdanffy, 1993), it might be supposed, that xylene targets this phase of the cell cycle. We are the first who observed the effect of xylene on ovarian testosterone release, as well as on bovine ovarian cells at all. Since progesterone and testosterone are commonly known promoters of ovarian cell differentiation, ovarian folliculo- and luteogenesis (Sirotkin, 2010), it is possible, that xylene can disrupt these processes via suppression of these steroid hormones release. Moreover, both progesterone and testosterone are the known regulators of ovarian cell proliferation (Sirotkin, 2010), therefore it cannot be excluded that xylene influences proliferation affecting these steroid hormone output. The stimulatory action of xylene on ovarian cell proliferation and its inhibitory effect on steroidogenesis can explain the adverse action of this environmental contaminant on fecundity observed previously (Ungváry et al., 1981; Sirotkin et al., 2012). Furthermore, the stimulatory action of xylene on cell proliferation observed in our experiments could explain the ability of xylene to induce malignant transformations which are characterized by increased cell divisions (Arp et al., 1983; Sirotkin et al., 2012). These direct effects of xylene on ovarian cells observed in our and previous studies should be taken into account when not only laboratory and farm animals but also humans are exposed to this contaminant.

In our experiments chia seed extract inhibited proliferation, apoptosis and the release of IGF-1, progesterone and testosterone by cultured bovine granulosa cells. These results are partially consistent with the report of Sirotkin et al. (2015) on cultured rabbit ovarian fragments and porcine granulose cells, who observed that chia seed extract was able to suppress the ovarian cell functions by inhibiting the accumulation of PCNA and Bax, and decreasing the release of IGF-1, progesterone and testosterone. Different patterns of influence of chia seed extract on apoptosis observed here and previously can be caused by using different animal models and possible species-specific differences in chia seed extract action on ovarian cell apoptosis. Moreover, our and previous observations suggest the positive influence and potential usefulness of chia seed extract on control of reproductive functions in different farm animals.

Mechanisms/mediators of chia seed extract effect require further studies. Till now there are no literature data concerning chia seed extract impact on mutual relationship between progesterone, testosterone, proliferation and apoptosis. Nevertheless, it might be hypothesized, that IGF-1 might be one of the mediators involved in this process. IGF-1 is known promoter of ovarian cell proliferation and steroidogenesis, and suppressor of their apoptosis (Sirotkin, 2010). Therefore it is possible, that the inhibitory action of chia seed extract on ovarian cell proliferation and steroidogenesis are due to its inhibitory action on IGF-1 production.

Chia seed contains phytoestrogens such as quercetin (Reyes-Caudillo et al., 2008; Ixtaina et al., 2011), which can inhibit human cell proliferation in vitro (Kim et al., 2002) and in vivo (Steiner and Pound, 2003). Our data of the up-regulation of proliferation and apoptosis by chia seed extract is in line with the observations of Štochmal'ová et al. (2013), who found, that quercetin had similar decreasing effects on porcine ovarian functions as chia seed extract. These data suggest that the down-regulation of ovarian cell proliferation and apoptosis may be caused by the presence of this phytoestrogen in examined chia seed extract.

The suppressive effect of chia seed extract on bovine ovarian cell functions observed in our experiment indicates that consumption of chia seed may have potentialy negative effect on farm animals reproductive functions. It cannot be excluded, that chia may be used in the regulation of animal reproduction including fertility and treatment of reproductive disorders, but this hypothesis requires validation with adequate in vivo studies.

Some negative effects of stress exerted on ovarian functions could be prevented or neutralized by some plants containing antioxidants and other adaptogens (Ungváry et al., 1981; Liang and Yin, 2010). We hypothesized, that chia seed containing these molecules may be used to modify/reverse some xylene effects on ovarian functions including fertility.

In our experiments chia seed extract was able to reduce the stimulatory xylene effect on proliferation, however xylene and chia seed extract given together increased apoptosis and release of IGF-1 and intensify the inhibition of progesterone secretion in cul- 
tured ovarian granulosa cells. No cumulative effect of xylene and chia seed extract was observed on release of testosterone.

In the literature, there is no information about the protective effects of chia seed against the action of xylene or other environmental contaminants. Therefore, our observations represent the first evidence that chia seed can be a plant protector of ovarian cells against toxic influence of xylene on ovarian cell proliferation (accumulation of PCNA). Mechanism of such protective effect require further elucidation, but the ability of chia seed extract to prevent proliferative effect of xylene observed in our experiments might be explained by its inhibitory influence on the release of IGF-1, promoter of cell division (see above). On the other hand, chia seed extract was able to suppress only one effect of xylene, negatively influencing other examined factors (e.g., apoptosis or progesterone release) when it was used simultaneously with xylene. It suggests that chia seed extract could not be potentially useful as natural protector against negative effect of xylene on the ovarian cell functions other than proliferation.

\section{Conclusions}

Direct effect of both xylene and chia seed extract on bovine ovarian cell proliferation, apoptosis and secretory activity was observed. Xylene can be promoter of ovarian cell proliferation and inhibitor of steroidogenesis. Chia seed extract was a suppressor of all analysed ovarian functions. Moreover, it was found for the first time that chia seed extract is able to suppress xylene effect on ovarian cell proliferation. On the other hand, chia seed extract used simultaneously with xylene negatively influence other examined factors (e.g., apoptosis or progesterone release). This may suggest that chia seed extract could not be potentially useful as natural protector against negative effect of xylene on animal production.

\section{Acknowledgements}

The authors would like to thank Ing. Ž. Kuklová and Mrs. K. Tóthová (Animal Production Research Centre in Nitra-Lužianky) for technical assistance. This study was funded by grant from the APVV-0854-11, APVV-0404-11, APVV15-0296, UGA VIII/32/2016 as well as from the project 'ZDRAVIE'. The authors would like also to extend their appreciation to the International
Scientific Partnership Program ISPP at King Saud University for funding this research work through ISPP\#0013 project.

\section{References}

Arp E.W. Jr, Wolf P.H., Checkoway H., 1983. Lymphocytic leukemia and exposures to benzene and other solvents in the rubber industry. J. Occup. Med. 25, 598-602

Connolly K.M., Bogdanffy M.S., 1993. Evaluation of proliferating cell nuclear antigen (PCNA) as an endogenous marker of cell proliferation in rat liver: a dual-stain comparison with 5-brom-2'deoxyuridine. J. Histochem. Cytochem. 41, 1-6, https://doi. org/10.1177/41.1.7678022

Huang S.-T., Chen A.P.-C., 2008. Traditional Chinese medicine and infertility. Curr. Opin. Obstet. Gyn. 20, 211-215, https://doi. org/10.1097/gco.0b013e3282f88e22

Ixtaina V.Y., Martínez M.L., Spotorno V., Mateo C.M., Maestri D.M., Diehl B.W.K., Nolasco S.M., Tomás M.C., 2011. Characterization of chia seed oils obtained by pressing and solvent extraction. J. Food Comp. Anal. 24, 166-174, https://doi. org/10.1016/j.jfca.2010.08.006

Kim I.Y., Kim B.-C., Seong D.H., Lee D.K., Seo J.-M., Hong Y.J., Kim H.-T., Morton R.A., Kim S.-J., 2002. Raloxifene, a mixed estrogen agonist/antagonist, induces apoptosis in androgenindependent human prostate cancer cell lines. Cancer Res. 62, 5365-5369

Liang Z.-H., Yin D.-Z., 2010. Preventive treatment of traditional Chinese medicine as antistress and antiaging strategy. Rrejuv. Res. 13, 248-252, https://doi.org/10.1089/rej.2009.0867

Makarevich A., Sirotkin A., 1999. Development of a sensitive radioimmunoassay for IGF-I determination in samples from blood plasma and cell-conditioned medium. Vet. Med. 44, 71-78

Münster E., 1989. Development of enzymatic-immunologic measuring techniques on micro-titration plates for determining testosterone and progesterone in the blood plasma (in German). PhD Thesis. Institute for Animal Production and Breeding, University of Hohemheim, Stuttgart (Germany)

Osborn M., Isenberg S., 1994. Immunocytochemistry of frozen and of paraffin tissue sections. In: J.E. Celis (Editor). Cell Biology: A Laboratory Handbook. Academic Press. San Diego, CA (USA), pp. 361-367

Prakash B.S., Meyer H.H.D., Schallenberger E., van De Wiel D.F.M., 1987. Development of a sensitive enzymeimmunoassay (EIA) for progesterone determination in unextracted bovine plasma using the second antibody technique. J. Steroid Biochem. 28, 623-627, https://doi.org/10.1016/0022-4731(87)90389-X

Reyes-Caudillo E., Tecante A., Valdivia-López M.A., 2008. Dietary fibre content and antioxidant activity of phenolic compounds present in Mexican chia (Salvia hispanica L.) seeds. Food Chem. 107, 656-663, https://doi.org/10.1016/j.foodchem.2007.08.062

Sirotkin A.V., 2010. Effect of two types of stress (heat shock/high temperature and malnutrition/serum deprivation) on porcine ovarian cell functions and their response to hormones. J. Exp. Biol. 213, 2125-2130, https://doi.org/10.1242/jeb.040626

Sirotkin A.V., 2011. Regulators of Ovarian Functions. Nova Science Publishers, Inc. Hauppauge, NY (USA)

Sirotkin A.V., Harrath A.H., 2014. Phytoestrogens and their effects. Eur. J. Pharmacol. 741, 230-236, https://doi.org/10.1016/j. ejphar.2014.07.057 

Sirotkin A.V., Kádasi A., Baláži A., Baková Z., Harrath H.A.,
MakarevichA.V., KolesárováA., Chrenek P., Kotwica J., Tóth T., 2012. Influence of petrochemical industry environmental contaminants on animal ovarian cells. J. Microbio. Biotechnol. Food Sci. 2, 517-525

Sirotkin A.V., Kadasi A., Stochmalova A., Alexa R., Balazi A., Harrath A.H., 2015. Food, drink and medical plants and their molecules can affect female hormones and reproductive functions. Endocr. Abstr. 38, P370, https://doi.org/10.1530/endoabs.38.P370

Steiner M.S., Pound C.R., 2003. Phase IIA clinical trial to test the efficacy and safety of Toremifene in men with high-grade prostatic intraepithelial neoplasia. Clin. Prostate Cancer 2, 24-31, https://doi.org/10.3816/CGC.2003.n.009
Štochmal'ová A., Kádasi A., Alexa R., Sirotkin A.V., 2013. The effect of quercetin and FSH o proliferation and apoptosis of porcine ovarian granulosa cells. The $4^{\text {th }}$ International Scientific Conference. Applied Natural Sciences. $1^{\text {st }}$ Edition. 1 CD-ROM [262 s.]. ISBN 978-80-8105-502-7. Applied natural sciences. Trnava: Univerzita sv. Cyrila a Metoda, 2013, CD-ROM, s. 230-235, http://www.slpk.sk/form/epc/prehlady/2014/FBP2014.pdf

Taskinen H., Kyyrönen P., Hemminki K., Hoikkala M., Lajunen K., Lindbohm M.-L., 1994. Laboratory work and pregnancy outcome. J. Occup. Med. 36, 311-319, https://doi. org/10.1097/00043764-199403000-00008

Ungváry G., Varga B., Horváth E., Tátrai E., Folly G., 1981. Study on the role of maternal sex steroid production and metabolism in the embryotoxicity of para-xylene. Toxicology 19, 263-268, https://doi.org/10.1016/0300-483X(81)90136-0 